WARRING OVER VALOR 


\section{WAR CULTURE}

\section{Edited by Daniel Leonard Bernardi}

Books in this series address the myriad ways in which warfare informs diverse cultural practices, as well as the ways cultural practices-from cinema to social media-inform the practice of warfare. They illuminate the insights and limitations of critical theories that describe, explain, and politicize the phenomena of war culture. Traversing both national and intellectual borders, authors from a wide range of fields and disciplines collectively examine the articulation of war, its everyday practices, and its impact on individuals and societies throughout modern history.

Tanine Allison, Destructive Sublime: World War II in American Film and Media Brenda M. Boyle and Jeehyun Lim, eds., Looking Back on the Vietnam War: Twenty-First-Century Perspectives

Jonna Eagle, Imperial Affects: Sensational Melodrama and the Attractions of American Cinema

H. Bruce Franklin, Crash Course: From the Good War to the Forever War

Aaron Michael Kerner, Torture Porn in the Wake of 9/11: Horror, Exploitation, and the Cinema of Sensation

David Kieran and Edwin A. Martini, eds., At War: The Military and American Culture in the Twentieth Century and Beyond

Delia Malia Caparoso Konzett, Hollywood's Hawaii: Race, Nation, and War

Nan Levinson, War Is Not a Game: The New Antiwar Soldiers and the Movement They Built

Matt Sienkiewicz, The Other Air Force: U.S. Efforts to Reshape Middle Eastern Media Since 9/11

Jon Simons and John Louis Lucaites, eds., In/visible War: The Culture of War in Twenty-First-Century America

Roger Stahl, Through the Crosshairs: The Weapon's Eye in Public War Culture Simon Wendt, ed., Warring over Valor: How Race and Gender Shaped American Military Heroism in the Twentieth and Twenty-First Centuries 
WARRING OVER VALOR

How Race and Gender Shaped American Military Heroism in the Twentieth and Twenty-First Centuries

EDITED BY

SIMON WENDT

ili

RUTGERS UNIVERSITY PRESS

New Brunswick, Camden, and Newark, New Jersey, and London 


\section{Library of Congress Cataloging-in-Publication Data}

Names: Wendt, Simon, editor.

Title: Warring over valor : how race and gender shaped American military heroism in the twentieth and twenty-first centuries / edited by Simon Wendt.

Description: New Brunswick : Rutgers University Press, [2018] | Series: War culture. | Includes bibliographical references and index.

Identifiers: LCCN 2017060240| ISBN 9780813597546 (cloth : alk. paper) | ISBN 9780813597539 (pbk. : alk. paper) | ISBN 9780813597553 (epub) | ISBN 9780813597577 (web pdf)

Subjects: LCSH: Heroes-United States-History—2oth century. | HeroesUnited States-History-21st century. | United States-Armed ForcesMinorities-History-2oth century. | United States-Armed ForcesMinorities-History—21st century. | United States-History, Military2oth century. | United States-History, Military-21st century.

Classification: LCC E745.W39 2018 | DDC 355.00973/0904-dc23

$\mathrm{LC}$ record available at https://lccn.loc.gov/2017060240

A British Cataloging-in-Publication record for this book is available from the British Library.

This collection copyright (C) 2019 by Rutgers, The State University of New Jersey Individual chapters copyright (C) 2019 in the names of their authors All rights reserved

No part of this book may be reproduced or utilized in any form or by any means, electronic or mechanical, or by any information storage and retrieval system, without written permission from the publisher. Please contact Rutgers University Press, 106 Somerset Street, New Brunswick, NJ 08901. The only exception to this prohibition is "fair use" as defined by U.S. copyright law.

The paper used in this publication meets the requirements of the American National Standard for Information Sciences-Permanence of Paper for Printed Library Materials, ANSI Z39.48-1992.

www.rutgersuniversitypress.org

Manufactured in the United States of America 